Lisbon - Malacca Port Cities Twin Conferences 2019 / 2020

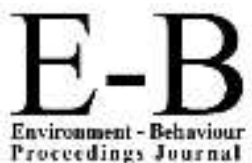

https://www.amerabra.org; https://fspu.uitm.edu.my/cebs; https://www.emasemasresources.com 9th Asia Pacific International Conference on Environment-Behaviour Studies,

Faculty of Architecture, Ulisboa, Lisbon, Portugal, 03-04 Jul 2019

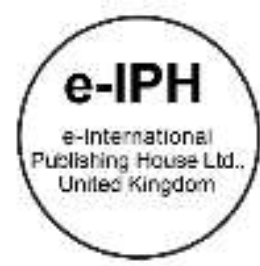

\title{
Using Traditional Ecological Knowledge to Adapt to Climate Change in Interior Sarawak
}

\author{
Nadzirah Hosen ${ }^{1}$, Hitoshi Nakamura², Amran Hamzah³ \\ 1 Graduate School of Engineering and Science, \\ 2 Department of Planning, Architecture and Environment Systems, \\ Shibaura Institute of Technology, Japan \\ ${ }^{3}$ Department of Urban and Regional Planning, Faculty of Built Environment and Surveying, \\ Universiti Teknologi Malaysia, Johor Bahru, MALAYSIA. \\ na17506@shibaura-it.ac.jp, nakamu-h@shibaura-it.ac.jp, merang@utm.my \\ Tel: +60127767871
}

\begin{abstract}
Indigenous people often rely on natural resources for their livelihoods. This reliance increases their vulnerability towards the impacts of climate change, and coping with increased climate variability is a significant challenge for such communities. This research, conducted among the Sa'ban tribe of Long Banga in interior Sarawak, Malaysia, explored observations of local climate change, climate change impacts and tribal adaptation strategies. The results show that drought, wildfires and uncertain weather conditions are the Sa'ban's primary concerns. However, the tribe have demonstrated their adaptation strategies through the use of traditional ecological knowledge (TEK).
\end{abstract}

Keywords: indigenous people, traditional ecological knowledge, adaptive capacity, climate change adaptation

eISSN: 2398-4287 @ 2019. The Authors. Published for AMER ABRA cE-Bs by e-International Publishing House, Ltd., UK. This is an open access article under the CC BYNC-ND license (http://creativecommons.org/licenses/by-nc-nd/4.0). Peer-review under responsibility of AMER (Association of Malaysian Environment-Behaviour Researchers), ABRA (Association of Behavioural Researchers on Asians) and cE-Bs (Centre for Environment-Behaviour Studies), Faculty of Architecture, Planning \& Surveying, Universiti Teknologi MARA, Malaysia.

DOI: https://doi.org/10.21834/e-bpj.v4i11.1716

\subsection{Introduction}

The survival of the indigenous Simeulueans in Sumatra and the Moken sea gipsies in Surin Islands from the Indian Ocean Tsunami in 2004 , stole the public attention over the last few years and sparked a new interest to the concept of indigenous knowledge. Both cases showcase how the indigenous communities survive the catastrophe events and deal with the challenging environmental situations using their century-old knowledge, the traditional ecological knowledge (TEK) (Meyers \& Watson, 2008; Arunotai, 2008). Most research discussed TEK in the context of natural resource management (e.g., Houde, 2007, Halim et al., 2012), but now there are efforts to include this knowledge in the climate change context (Vinyeta \& Lynn, 2013). More notably, the Paris Agreement has recognised indigenous people and their traditional system as part of the solution to climate change. The insight is valuable to foster adaptation and resilience during calamities that it strengthens the community capacity to deal with any disturbance.

\subsection{The role of TEK in climate change adaptation}

TEK refers to an intergenerational knowledge, practice and belief system on the relationship of living things with one another and with their environment that has evolved by adaptive processes (Berkes, 1993). Climate change adaptation, on the other hand, means to adjust and respond to the climate change risks and taking appropriate action to reduce the impacts of climate change or identify opportunities that may arise (Fankhauser, 2017). Indigenous people are responding and adapting to climate changes based on TEK. It

eISSN: 2398-4287 (C) 2019. The Authors. Published for AMER ABRA cE-Bs by e-International Publishing House, Ltd., UK. This is an open access article under the CC BYNC-ND license (http://creativecommons.org/licenses/by-nc-nd/4.0/). Peer-review under responsibility of AMER (Association of Malaysian Environment-Behaviour Researchers), ABRA (Association of Behavioural Researchers on Asians) and cE-Bs (Centre for Environment-Behaviour Studies), Faculty of Architecture, Planning \& Surveying, Universiti Teknologi MARA, Malaysia.

DOI: https://doi.org/10.21834/e-bpj.v4i11.1716 
gives the community the ability to track changes in their local surroundings and develop local coping strategies. This ability embedded in the TEK typologies. There are four interrelated TEK categories favourable in the climate change context, namely (1) local knowledge of the environment, (2) land and resource management systems, (3) social institutions and networks, and (4) worldview and belief systems (Figure 1).

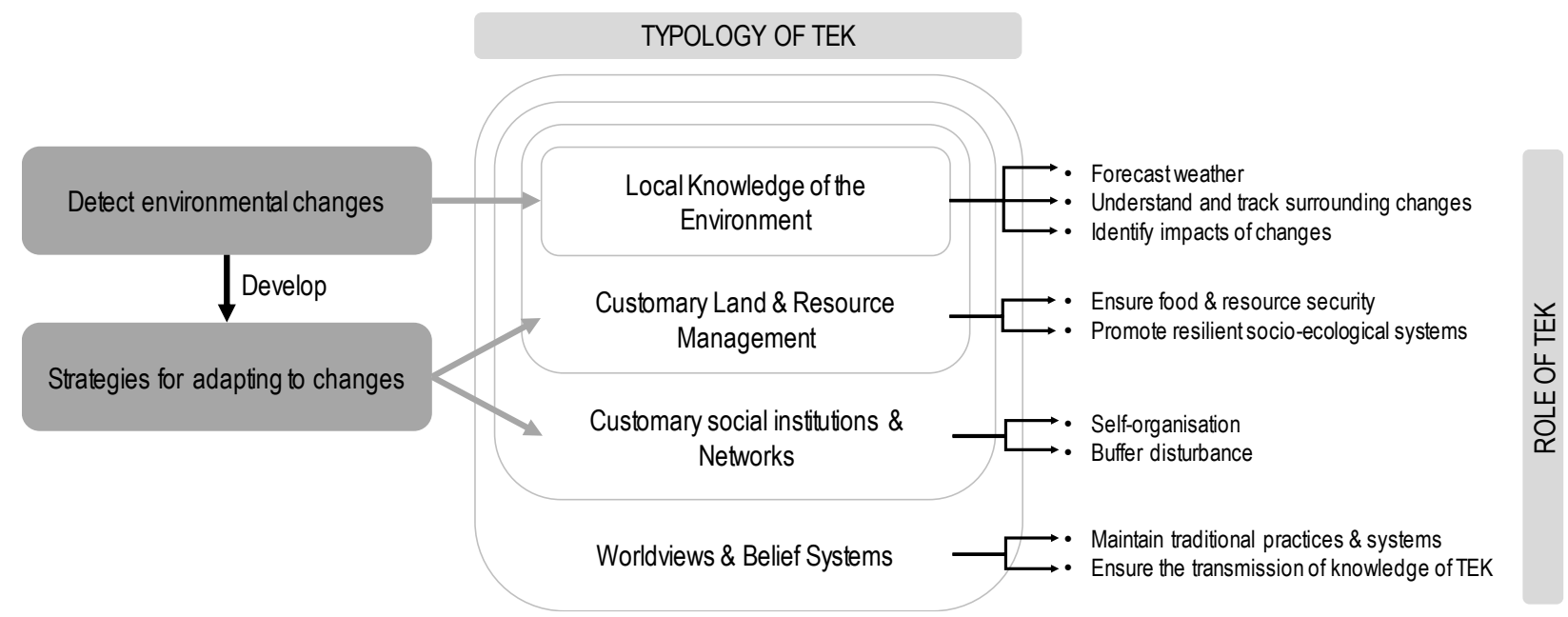

Fig. 1: The role of TEK in Climate Change Adaptation

(Source: Hosen \& Nakamura, 2019)

\subsection{Local knowledge of the environment}

It encompasses an understanding of flora, fauna, landscapes and soil, including their taxonomy, behaviour and distribution (Berkes, 2017; Houde, 2007; McMillen et al., 2017). It allows indigenous people to understand the ecosystem functions, including the interactions of animal and plants within it as well as the biophysical environment, which influences the community behaviour (Freeman, 1992). For example, bioclimatic indicators such as the length of precipitation, sky coverage, wind speed and the cycle events of periodic plant and animal life help the indigenous community to sense changes in weather and season. These elements correspond to their subsistence activities in terms of the timing of agriculture, gathering, hunting and fishing (e.g. Garay-Barayazarra et al., 2011; Leonard et al., 2013; Kuhnlein et al., 2006; Prober et al., 2011). Owing to this reason, indigenous people are highly responsive to changes in their surroundings.

\subsection{Customary land and resource management}

This management system is the way that the indigenous people manages their terrestrial and marine ecosystems which have evolves through adaptive processes (Leonard et al., 2013; McMillen et al., 2014). It helps the community to prepare for the anticipated hazard by modifying practices and developing appropriate technologies. In the case of food security, for instance, they will ration, diversify or store their resources as a precaution as well as to provide option during shocks (Berkes et al., 2000; Gómez-Baggethun et al., 2012). For example, they enforce some temporary restriction of harvesting in planting, gathering, hunting and fishing to response to common shortages and to allow the renewal of surrounding ecosystems (Ingty, 2017; McMillen et al., 2014). These practices consequently build their capacity, thus enhance community resilience.

\subsection{Customary social institutions and networks}

These elements are the social attributes in climate change adaptation. It deals with the social cohesion of the community and the ability to cooperate in buffering against climate disturbance and promoting self-organisation. The key to creating a cohesive society within the indigenous community lies in this facet of TEK. Well-built community ties enable them to share assets and resources during the anticipated hazards which in turns, guarantee resource availability and diversity in a time of crises (Agrawal \& Perrin, 2008; GómezBaggethun et al., 2012). Good local leadership and institutions, on the one hand, are necessary to avert calamities. They contribute to efficient allocation systems, promote social cohesion within community, store collective memory and support sustainability (Brown \& Sonwa, 2015; Gómez-Baggethun et al., 2012; Ingty, 2017).

\subsection{Customary social institutions and networks}

As the final facet of TEK, it becomes the foundation of the whole knowledge system. It becomes a mechanism for intergenerational accumulation and transmission of knowledge (Berkes et al., 2000) and often takes place in the form of oral tradition, taboos, ceremonies and festivals. Apart from sustaining the TEK, it also strengthens the social networks within the community and maintains the reciprocity relationship through information and resources exchange. According to Ziegler (2007), they foster the bond among the exchange parties by creating trust, and they can reckon on this relationship, thus ensure resilient resource access during crises.

Despite the relevance of TEK in the climate change context, its documentation is still under-researched, especially in the Malaysian context. Therefore, the objective of this paper is to explore and document the role of TEK in the climate change adaptation using a TEK 
typology. This documentation will help to provide understanding of how the knowledge systems amassed over generations can continue to adjust and improve the communities respond to today's climate.

\subsection{Methodology}

\subsection{Study area}

In the Marudi Division of Sarawak, Long Banga is one of the most isolated villages in the upper Baram river which lies approximately $373 \mathrm{~km}$ from the nearest town Marudi. Only four-wheeled-drive vehicles can access the unpaved logging road that connects it to most of the areas. They have the Long Banga STOLport which offers twice a week flights to Miri and Marudi using the DHC-6 Twin Otter. The number of population is about 500 people, dominated by the Sa'ban community. Agriculture is the main economic activities, with some of the villagers open up small enterprises. Electricity supply is primarily from micro-hydro dam, whereas water supply comes from the mountain stream. Currently, the government provides them with one primary school (SK Long Banga), a STOLport, a church and a clinic.

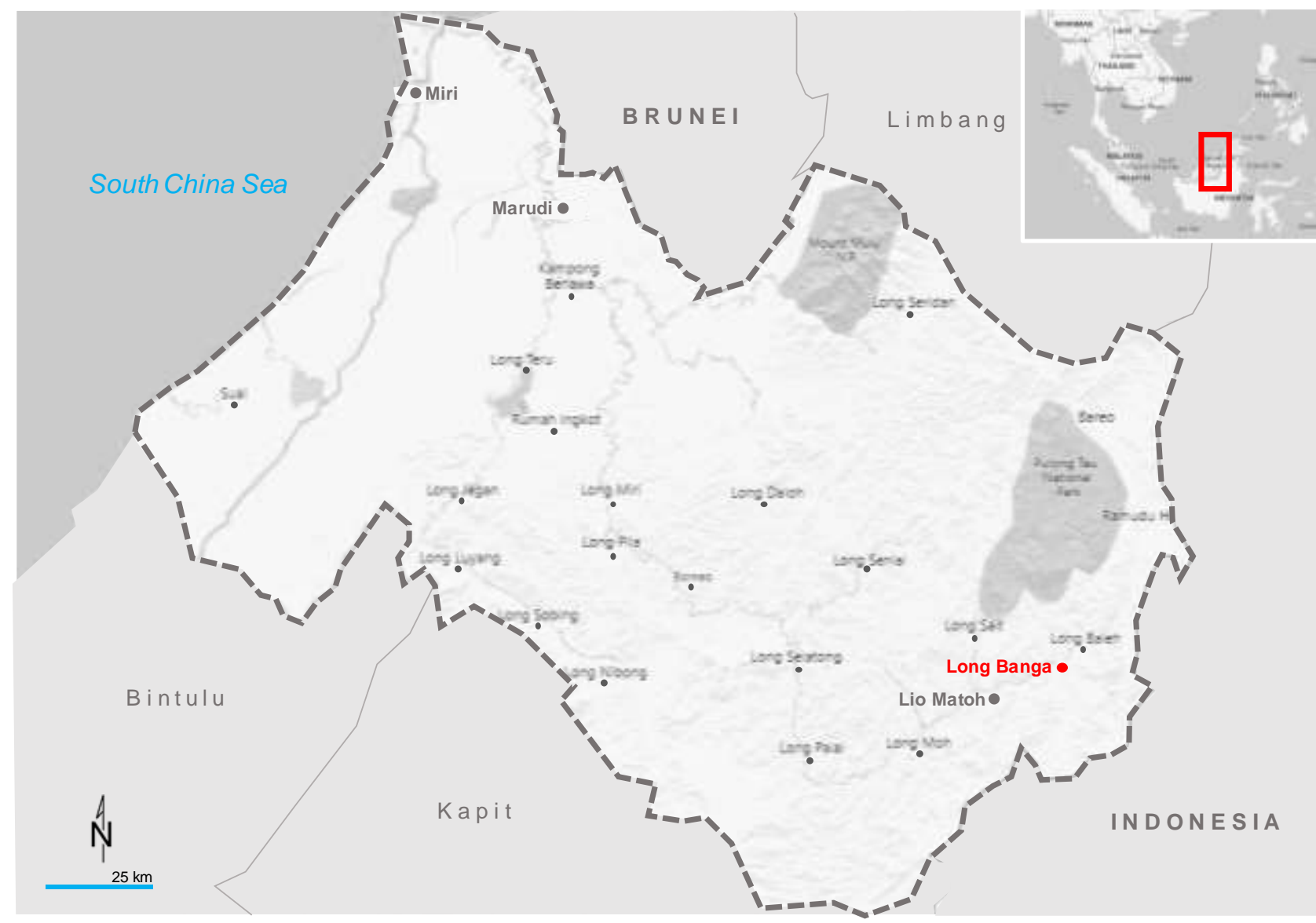

Fig. 2: Location of the study area

\subsection{Data collection and analysis}

Collection of data was done in January 2019 using an interview with key informants and field observation. The questionnaire did not specifically focus on the term 'climate change', but on broad environmental changes related to weather and seasons, and their impacts on the livelihood of the local community. This technique creates a more informal conversation with the villagers and resulting in more informed dialogue. The interviewer also asks questions regarding their local strategies to manage the environmental impacts to get a clear view of the role of TEK in climate change adaptation. Ten key informants were identified using a snowball sampling technique. Table 1 shows the demographic profiles of the key informants. Data were then analysed using a qualitative thematic analysis. It is a method used in qualitative research to analyse patterns within data (Cassol et al., 2018) and help identify issues need to be tackled. 
Table 1. Demographic profiles of the key informants

\begin{tabular}{ll}
\hline Demographic Profile & Key Informant \\
\hline Total Sample & 10 \\
Sex & \\
Male & 6 \\
Female & 4 \\
& \\
Age group & \\
$81-30$ & 0 \\
$31-45$ & 2 \\
$46-65$ & 2 \\
$65+$ & 6 \\
& \\
Education & \\
None & 6 \\
Primary & 1 \\
Secondary & 3 \\
Tertiary & 0 \\
Main Income & \\
Farming & \\
Small business & 8 \\
\hline
\end{tabular}

(Source: Field survey, 2019)

\subsection{Results}

The Sa'ban tribe possessed unique ways of adapting to climate change risks using the TEK. Table 2 summarises their traditional strategies in Long Banga based on four elements in the TEK typology.

Table 2. Traditional strategies identified by the Lun Bawang tribe for addressing climate variability and change on Bakelalan highland

\begin{tabular}{|c|c|c|}
\hline Typology of TEK & Role of TEK & Result \\
\hline $\begin{array}{l}\text { Local knowledge of the } \\
\text { environment }\end{array}$ & $\begin{array}{l}\text { - Forecast weather } \\
\text { - Understand and track } \\
\text { surrounding changes } \\
\text { - Identify the impacts of } \\
\text { changes }\end{array}$ & $\begin{array}{l}\text { - Bioclimatic indicators: } \\
\text { - Teng moon in the lunar } \\
\text { cycle } \\
\text { - Changes observed: } \\
\text { - Increase in temperature } \\
\text { - Uncertain weather } \\
\text { condition } \\
\text { - Impacts of changes: } \\
\text { - Erratic rainfall } \\
\text { - Drought events } \\
\text { - Wildfires }\end{array}$ \\
\hline $\begin{array}{l}\text { Customary land and resource } \\
\text { management }\end{array}$ & $\begin{array}{l}\text { - Ensure food and resource } \\
\text { security } \\
\text { - Promote resilient socio- } \\
\text { ecological systems }\end{array}$ & $\begin{array}{l}\text { - Shifting cultivation of padi } \\
\text { iraang } \\
\text { - Storing resources in paau } \\
\text { padi } \\
\text { - Diversification of resource: } \\
\text { éra.' } \\
\text { - Community forest }\end{array}$ \\
\hline $\begin{array}{l}\text { Customary social institutions } \\
\text { and networks }\end{array}$ & $\begin{array}{l}\text { - Self-organisation } \\
\text { - Buffer disturbance }\end{array}$ & $\begin{array}{l}\text { - Cultural philosophy: } \\
\text { Si'sawai, Si'hnau, Si'lawai } \\
\text { - Community pooling: Ledu' } \\
\text { - Community leader: the lún } \\
\text { rah lem awéeng } \\
\text { - Church institution: maa' } \\
\text { tempún and their mah maa' } \\
\text { tempún } \\
\text { - Madei' practice }\end{array}$ \\
\hline $\begin{array}{l}\text { Worldviews and belief } \\
\text { systems }\end{array}$ & $\begin{array}{l}\text { - Maintain traditional practices } \\
\text { and systems } \\
\text { - Ensure the transmission of } \\
\text { knowledge of TEK } \\
\text { (Source: Field survey, 2019) }\end{array}$ & $\begin{array}{l}\text { - Sembayaang (before } \\
\text { harvest ceremony) } \\
\text { - Ngkui (after harvest festival) }\end{array}$ \\
\hline
\end{tabular}

\subsection{Local knowledge of the environment}

Understanding change in the local surrounding is significant for the Sa'ban tribe to manage their subsistence activities, especially rainfed agriculture, hunting and fishing. Careful observation of the climatic factors such as rainfall and dry day is essential as they affect local livelihoods. Traditionally, they have an annual planting calendar consists of two seasons, the 'wet season' which is from October to 
February characterised by heavy precipitation and the 'dry season', from March to September with drier and higher temperature. According to the interview with the Sa'ban, they observed significant changes in the weather and seasonal patterns.

These changes consequently affect the Sa'ban staple food, 'padi iraang', a Sa'banese word that translates to 'upland rice'. The agronomic practice of the upland rice is different from the wet rice farming whereby its cultivation is heavily dependent on both seasons. The dry season is the best time for land preparation for the next planting season, whereas the wet season with heavy rain provides perfect conditions to grow the rice. In the dry season, the activities include land clearance, which involves cutting down the trees and grass. The area is left to dry for about a month before burning event takes place to clear the area entirely. Therefore, the best time for this practice is during the dry season. Towards the end of the dry season in August, they will start to dibble the land for seed sowing. It will then get continuous water supply from the rain during the wet season for their growth.

One of the bioclimatic indicators that they utilised to start the dibble sowing is by observing the lunar cycle or the phases of the moon. According to the villagers, when they see the 'Teng' moon, the 'first quarter moon' during the night in August, they will start the dibble sowing the next day. According to them, the moon shape indicates that rainfall is near that they should begin to plant the seed. However, this indicator is no longer reliable due to shifting weather and seasons, thus affecting their food production and supply. The rain features abrupt variations; sometimes it is plentiful at an unexpected time, sometimes it is less for a more extended period. It not only disturbs the rice but other activities as well, such as fishing.

Another significant change that the tribe observed is the increase in the surrounding temperature. According to the community, the weather is much warmer than it used to be. The hotter and drier season has consequently led to droughts. Unfortunately, the prolonged droughts have caused a bigger disaster, the wildfire events. During the event, the fire burnt the surrounding virgin forest in Long Banga, and the fire spread within the soil to Lio Matoh, approximately $17 \mathrm{~km}$ long. Due to prolonged dry spell, this event lasted for two to three months and burned all the crops and resources in the forest that the tribe depend, which eventually caused significant loss to the villagers.

Uncertain weather and seasonal patterns, increase in surrounding temperature, drought and wildfire events give significant impact to the tribe livelihood, which undermines their food security. The community learned from the disasters, and thus manage their resources to ensure that food is always available all year round. The next section explains these practices.

\subsection{Customary land and resource management}

Climate change poses threats to the Sa'ban tribe who heavily dependent on the natural resources and monsoon climate for their agriculture. However, living in an isolated region and many years of facing environmental extremes have made them ready for the anticipated hazards. Due to unpredictable weather, they become more conscious to ensure that resources are available all year round through their traditional harvesting practices, land and resource management.

For hundreds of years ago, rice has been and continuously become the staple food for the Sa'ban. The cultivation of 'padi iraang' is the Sa'ban farming tradition passed from generations to maintain rice production every year. Compared to the wet rice farming, the 'padi iraang' grown on dry soil and upland terrain. The indigenous technology applies to it is shifting cultivation. The basic concept of this agricultural technique is; the rotation of long season of fallow with a short season of farming which involves a repeated shift of fields and the use of fire to remove natural vegetation (Erni, 2008). The method begins with 'temaraa" (cutting down trees and other woody plants) and 'lemdiek' (slashing the undergrowth). They were then left to dry before 'ntueng' takes place, the burning of dried vegetation to create nutrient-rich ashes that make the soil fertile in addition to eliminating the weed and pest temporarily. They will then start the seed sowing right before the wet season comes. The rice grew and harvested when it matures. In the next planting season, they repeat the cycle but in other fields. The empty field, on the other hand, is let to rest for four to five years, allowing for regeneration of vegetation that will become trees.

The Sa'ban claimed that through this method, the soil fertility is maintained persistently for years, that the rice will grow well and produce surplus yield. The tribe then keep the surplus in the Paau Padi, or the paddy store, to ensure that they will have a continuous supply of food even when disaster strikes them, thus relieve food scarcity during the crises.

Apart from 'padi iraang', every family establish an 'éra'; it is an integrated home garden characterised by a traditional land use system where they grow numerous species of plants as their secondary crop. Some example of crops in their backyard are bananas, sweet potato, manioc and other vegetables and fruits. Most of these varieties are relatively resistant to drought. Sometimes, it also includes poultry, livestock and fish. Occasionally the villagers use the old fallow field as their era and plant other secondary crops to maximise their food security such as maize, pumpkin and other vegetables. Higher and diversified agroecosystems help them to adapt to climate extremes such as droughts and wildfires because if other resources are damaged, the food supply is still available in another part. It happens to the tribe when the largest wildfires stroke them in the 1990s that burned all the 'padi iraang' and resources in the forests such as wild fruits and vegetables. Luckily their 'éra' and 'paau padi' are not affected, thus secure the food resources.

Besides, the Sa'ban has a community forest reserve that was conserved and protected from any logging activities. The conservation effort helps to maintain ecosystem integrity which allows the community to buffer local climate, thus reducing the risks and impacts from extreme events. Moreover, the community forest reserve supports essential ecosystem services which provide them with water, wild meat, fish and traditional medicine.

\subsection{Customary social networks and institutions}

The ability to cooperate determines the capacity of society to adapt (Adger, 2003). The Sa'ban highlighted their tribe philosophy, the "Si'sawai, Si'hnau, Si'lawai" as the root of their social strategies in building adaptive capacity to environmental challenges. Carrying the meaning of "one heart, one mind and one goal", this philosophy unites and strengthens the kinship of the community. The tribe noted 
that it enables collective action and reciprocity wherever they are especially during hard times. For example, they work together to protect their village when wildfires stroke them a few years ago. They also perform collective action during the planting season because 'padi iraang' is a strenuous work that it needs a large workforce.

Moreover, the Sa'ban is practising 'ledu", which is a type of community pooling action. It means to help one in needs during crises. According to them, the whole community will help those who experience food shortages due to drought or other disasters, by sharing resources and labour.

Additionally, the 'lún rah lem awéeng' or the headman is the respected community chief and becomes the reference before they make any decision. He also leads the implementation of the values discussed above, drives collective actions and manages conflicts. Another institution that helps the community to self-organise and buffers against disturbance is the 'maa' tempún' or the church. Remarkably, it owns a rice farm ('mah maa' tempún'), which aims to help those who ran out of rice during the year due to a bad harvest. Through this farm, the community will work together on the field in all respects, and the yield produced from the farm given to those in need as a loan. This cooperation enhances unity within the community and provides insurance against food crises.

\subsection{The worldview and belief systems}

The worldview and belief systems help the Sa'ban to pass down the knowledge for generations. In their community, the transmission starts from the family unit through 'madei", to advise and to show practically. In this practice, the older folks will advise the youngster about the importance of their traditions. 'Madei" can take place in different locations, either during dinner or lunch time when everyone in the family gathers or in the farm when they bring along their child and teach them about traditional farming and how to secure food resources.

Moreover, social functions such as ceremonies and festivals play essential roles for knowledge transmission and build strong social cohesion within the community. Before the seed sowing, they will perform the sembayaang ceremony in the church to ask for a good harvest and avoid hazards. Next, after the harvesting, they will celebrate 'Ngkui', a Sa'ban after harvest festival to celebrate the harvested rice and as a sign of gratitude. In both events that the community gather and learn about their culture as well as sharing information and resources. Consequently, it strengthens the reciprocity relationship that they can rely on when disaster strikes.

\subsection{Discussion}

The results reveal the application of TEK in the Sa'ban way of life. The first facet of TEK helps the tribe to detect changes in their surroundings. Significant changes that they experienced include shifting in weather and seasons featuring erratic rainfall and an increase in the temperature. It also exposes the vulnerability of the tribe to droughts and wildfire events. A significant aspect is that the bioclimatic indicators used formerly to manage everyday lives are now out of sync. In response to these climatic challenges, the tribe manage their land and resources using the second facet of the TEK. They practice traditional long-fallow shifting cultivation for their upland rice which consequently benefits both the community and biodiversity. Their agricultural lands are highly diverse characterised by a mosaic of vegetation including home gardens, fallow land, annual crops, natural forest and community forest. This diversity now becomes the central element in adaptation strategies to climate change which helps to spread risk across space and time. The method of storing stocks as well has made them more resilient to climate stresses. In the third facet of TEK, the tribe philosophy becomes the basis of their social network that promotes social cohesion. More notably, the headman and the Church institution act as oils to wheel the reciprocity network among the community and promote collective actions in responding to climate difficulties, thus reducing vulnerabilities. Finally, the last facet of TEK hold the three elements together and transmits knowledge from generations to generations through ceremonies and festivals. Older folks seem to be a vital knowledge holder which the community respect.

However, the tribe expresses their concerns regarding losing the TEK. Many young people migrate to urban area for studying and working, thus leaving their parents to work on traditional farming alone. Due to changes in lifestyle and modernisation, not many young people are interested in living in an isolated village, though they will come back for festivals which usually happens once a year. Also, the tribe worried about continuous deforestation by the logging company which impacted the forest resources they depend. Deforestation also decreases the number of trees that helps to capture carbon dioxide levels, thus increasing the severity of climate change impacts to the local community.

\subsection{Conclusion \& Recommendation}

For hundreds of years, the Sa'ban has lived in harsh environments which enable them to cope with environmental extremes. This research proves that TEK helps them to track changes and offer a method for building adaptive capacity in the face of climate change. TEK is a practical tool to adapt to climate risks and vulnerabilities, thus promote community-based adaptation. Therefore, this knowledge system needs further support from the science-based knowledge and modern technologies. Finally, policymakers and practitioners need to consider and integrate TEK into local planning and policy in Malaysia to legitimise this knowledge system in the climate change adaptation context.

\section{References}

Adger, W. N., (2003). Social Capital, Collective Action, and Adaptation to Climate Change. Economic Geography, 79 (4), $387-404$ 
Agrawal, A., and Perrin, N. (2008). Climate adaptation, Local Institutions and Rural Livelihoods. IFRI Working Paper (Vol. W081-6), (2008).

Arunotai, N., (2008). Saved by an Old Legend and a Keen Observation: The Case of Moken Sea Nomads in Thailand. In Indigenous Knowledge for Disaster Risk Reduction: Good Practices and Lessons Learned from Experiences in the Asia-Pacific Region. Bangkok: UNISDR.

Berkes, F., (1993). Traditional ecological knowledge in perspective. Traditional Ecological Knowledge: Concepts and Cases, J.T. Inglis, Ed., Canadian Museum of Nature/International Development Research Centre, International Program on Traditional Ecological Knowledge International Development Research Centre, 1-9.

Berkes, F., Colding, J., and Folke, C., (2000) Rediscovery of Traditional Ecological Knowledge as Adaptive Management. Ecological Applications, Volume 10 (5), $1251-$ 1262.

Berkes, F., (2017). Sacred Ecology (Fourth). New York: Routledge,

Brown, H. C. P., \& Sonwa, D. J., (2015). Rural local institutions and climate change adaptation in forest communities in Cameroon. Ecology and Society, 20 (2), 6.

Cassol, H., Charland-verville, V., \& Bragard, I., (2018) Qualitative thematic analysis of the phenomenology of near-death experiences. Plos One, 13 (2), 1-14.

Erni, C., (2008). The Concept of Indigenous Peoples in Asia. A Resource Book. Copenhagen/Chiang Mai: IWGIA and AIPP European Commission

Fankhauser, S., (2017). Adaptation to Climate Change. Annual Review of Resource Economics, 9, 209-230

Freeman, M. M. R., (1992). The Nature and Utility of Traditional Ecological Knowledge. Northern Perspectives, 20 (1), 9-12.

Garay-Barayazarra, G. and Puri, R. K., (2011). Smelling the monsoon: Senses and traditional weather forecasting knowledge among the Kenyah Badeng farmers of Sarawak, Malaysia. Indian Journal of Traditional Knowledge, 10 (1), 21-30.

Gómez-Baggethun, E., Reyes-García, V., Olsson, P., \& Montes, C., (2012) Traditional ecological knowledge and community resilience to environmental extremes: A case study in Doñana, SW Spain. Global Environmental Change, 22 (3), 640-650.

Halim, A. A., Jawan, J. A., Ismail, S. R., Othman, N., and Ibrahim, N. N., (2012). Indigenous Knowledge and Biodiversity Conservation in Sabah, Malaysia. International Journal of Social Science and Humanity, 2(2), 159-163.

Hosen, N \& Nakamura, H., (2019). Conceptualising the Role of Traditional Ecological Knowledge (TEK) in Climate Change Adaptation. The 3rd International Conference on Climate Change 2019, 1-9.

Houde, N., (2007). The six faces of traditional ecological knowledge: Challenges and opportunities for Canadian co-management arrangements. Ecology and Society, 12(2), 34 .

Ingty, T., (2017). High mountain communities and climate change: adaptation, traditional ecological knowledge, and institutions. Climatic Change, 145(1-2), 41-55.

Kuhnlein, H., Erasmus, B., Creed-Kanashiro, H., Englberger, L., Okeke, C., Turner, N., ... Bhattacharjee, L., (2006) Indigenous peoples' food systems for health: Finding interventions that work. Public Health Nutrition, 9 (8), 1013-1019.

Leonard, S., Parsons, M., Olawsky, K., and Kofod, F., (2013). The role of culture and traditional knowledge in climate change adaptation: Insights from East Kimberley, Australia. Global Environmental Change, 23(3), 623-632.

McMillen, H. L., Ticktin, T., Friedlander, A., Jupiter, S. D., Thaman, R., Campbell, J., ... Orcherton, D. F., (2014). Small islands, valuable insights: Systems of customary resource use and resilience to climate change in the Pacific. Ecology and Society, 19(4).

McMillen, H., Ticktin, T., and Springer, H. K., (2017). The future is behind us: traditional ecological knowledge and resilience over time on Hawaifi Island. Regional Environmental Change, 17(2), 579-592.

Meyers, K. \& Watson, P., (2008). Legend, Rltual and Architecture on the Ring of Fire. in Indigenous Knowledge for Disaster Risk Reduction: Good Practices and Lessons Learned from Experiences in the Asia-Pacific Region. UNISDR: Bangkok.Prober et al., 2011

Vinyeta, K., \& Lynn, K., (2013). Exploring the Role of Traditional Ecological Knowledge in Climate Change Initiatives. Gen. Tech. Rep. PNW-GTR-879. Portland, OR: U.S. Department of Agriculture, Forest Service, Pacific Northwest Research Station

Ziegler, R., (2007). The Kula Ring of Bronislaw Malinowski: A Simulation Model of the Co-Evolution of an Economic and Ceremonial Exchange System. Review of European Studies, 4(1). 